\title{
PENGARUH KEPUASAN KONSUMEN TERHADAP PERILAKU PEMBELIAN ULANG KONSUMEN PADA CAFÉ DAN RESTO BANGI KOPITIAM DI KOTA PALU
}

\author{
Anshar Rahman Mas'ud \\ Elimawaty Rombe \\ Engki P. Nainggolan \\ Jurusan Manajemen, Fakultas Ekonomi, Universitas Tadulako \\ Email: ansharrachman69@gmail.com
}

\begin{abstract}
This study aims to determine and analyze simultaneous and partial influence of consumer satisfaction on repurchase behavior in Bang Kopitiam Café and Resto in Palu City. The type of research is quantitative. The population in this study involves consumers who have visited Bangi Kopitiam Café and Resto at least 2 times. Sampling technique is accidental method, with sample of 90 respondents. Data collection using questionnaires. Data analysis tool is multiple linear regressions method. The result shows that consumer satisfaction simultaneously and partially influence repurchase behavior of consumers in Bangi Kopitiam Café and Resto Palu City. Keywords: consumer satisfaction and repurchase behavior
\end{abstract}

\begin{abstract}
ABSTRAK
Penelitian ini bertujuan untuk mengetahui dan menganalisa pengaruh serempak dan partial kepuasan konsumen terhadap perilaku pembelian ulang konsumen di Bangi Kopitiam Café and Resto. Jenis penelitian adalah kuantitatif (menunjukkan hubungan antar variabel). Populasi dalam penelitian ini adalah konsumen yang telah mengunjungi Bangi Kopitiam Café and Resto minimal 2 kali. Teknik penarikan sampel dalam penelitian ini menggunakan accidental sampling, dengan jumlah sampel sebanyak 90 responden. Pengambilan data menggunakan kuesioner. Metode analisis data adalah linear regresi berganda. Hasil penelitian menunjukkan bahwa kepuasan konsumen secara serempak dan partial berpengaruh signifikan terhadap perilaku pembelian ulang konsumen pada Bangi Kopitiam Café and Resto di Kota Palu.
\end{abstract}

Kata Kunci: kepuasan konsumen, pembelian kembali.

\section{PENDAHULUAN}

Beraneka ragam produk makanan dan minuman pada usaha indusrti di Kota Palu yang banyak diminati konsumen telah mengubah pola konsumsi masyarakat yang saat ini terlihat jelas dengan semakin banyaknya bermunculan cafe dan resto seperti: Black Canyon Coffee, Max coffee, Excelso dan cafe dan resto yang ada di Kota Palu. Menjadi tanda bahwa semakin meningkat juga pola konsumsi masyarakat pada produk makanan dan minuman. Persaingan yang semakin ketat inilah yang saat ini sedang terjadi di dunia industri. Hal ini seiring dengan semakin pesatnya perkembangan usaha industri di Kota Palu. Dengan demikian, persaingan antar pembuat cafe dan resto untuk merebut hati konsumen yang semakin tinggi.

Ada berbagai jenis cafe dan resto, alasan penulis memilih cafe dan resto Bangi Kopitiam karena tempatnya yang mudah dijangkau dekat pusat Kota Palu. Cafe yang terletak di Jalan Cumi-Cumi No.26, resmi beroperasi pada 10 Oktober 2014, Meski baru 3 tahun berjalan. Namun respon masyarakat di Kota Palu ini sudah sangat luar biasa, karena cafe dan resto Bangi Kopitiam memiliki kemampuan yang baik dalam memenuhi kepuasan konsumen. Dengan target konsumen kalangan menengah ke atas. Bangi Kopitiam tampil sebagai cafe dan resto moderen khas Kota-kota besar. Tidak mengherankan dari berbagai kalangan Siswa, Mahasiswa, Pegawai dan lain-lain khususnya yang di Kota Palu menjadikan tempat ini sebagai gaya hidup baru. 
Cafe dan resto Bangi Kopitiam merupakan Franchise asal Malaysia. Di indonesia sendiri, cafe dan resto Bangi Kopitiam pertama kali dibangun di Pesanggerahan, 2011 silam. Hingga kini cafe dan resto Bangi Kopitiam sudah mempunyai 80 outlet di Indonesia, termasuk di Kota Palu. Cafe dan resto Bangi Kopitiam tetap konsisten dengan menu khasnya dari asalnya Malaysia, yakni 70\% menu Melayu, 10\% menu Barat, $10 \%$ menu China dan $10 \%$ lagi, tentu saja dari kuliner khas Indonesia.Ini pula yang membedakan Bangi Kopitiam dengan cafe-cafe sejenis dan kelasnya. Untuk minuman, cafe dan resto Bangi Kopitiam mengandalkan teh dan kopi tarik yang merupakan minuman khas Melayu sementara untuk makanan ringannya adalah malacca portugese toast atau Roti Panggang isi mentega. Dua menu andalan ini memang tak akan di dapatkan di cafe manapun karena bahannya impor langsung dari Malaysia.

Fenomena persaingan ini menuntut para pemasar untuk selalu menginovasi strategi bisnisnya. Untuk menghadapi persaingan pemasaran produk tersebut, untuk mempertahankan konsumen dan memperluas pangsa pasar (market share), maka setiap perusahaan harus memiliki kemampuan untuk memuaskan konsumennya. Kekhawatiran produsen yang terjadi akibat kondisi persaingan yang semakin ketat dan beragamnya merek produk yang ditawarkan, dan di satu sisi yang lain konsumen tidak mampu mengingat semua produk yang ditawarkan sehingga hanya produk yang memiliki ciri khas atau pun yang memiliki citra merek yang kuat saja yang mampu membedahkan dengan produk yang lainnya yang akan mudah diingat oleh konsumen, jadi jika sebuah merek sudah dikenal dan kemudian dalam benak konsumen ada asosiasi tertentu terhadap sebuah merek, sehingga merek tersebut dapat dibedahkan dengan merek-merek yang lain, lalu di benak konsumen, merek tersebut dipersepsikan memiliki kualitas yang tinggi dan berhasil membuat konsumen puas serta menjadi pertimbangan dalam melakukan keputusan pembelian ulang. Untuk mengetahui hal tersebut, perlu dilakukan kajian lebih mendalam melalui penelitian dengan tujuan:

1. Untuk mengetahui pengaruh secara simultan dimensi dari kepuasan konsumen yang terdiri dari atribut yang berhubungan dengan produk $\left(\mathrm{X}_{1}\right)$, atribut yang berhubungan dengan pelayanan $\left(\mathrm{X}_{2}\right)$ dan atribut yang berhubungan dengan pembelian $\left(\mathrm{X}_{3}\right)$. Secara simultan berpengaruh terhadap perilaku pembelian ulang (Y) konsumen di cafe dan resto Bangi Kopitiam di Kota Palu.

2. Untuk mengetahui dan menganalisis pengaruh atribut yang berhubungan dengan produk $\left(X_{1}\right)$, berpengaruh terhadap perilaku pembelian ulang $(\mathrm{Y})$ konsumen di cafe dan resto Bangi Kopitiam di Kota Palu.

3. Untuk mengetahui dan menganalisis pengaruh atribut yang berhubungan dengan pelayanan $\left(\mathrm{X}_{2}\right)$, berpengaruh terhadap perilaku pembelian ulang (Y) konsumen di cafe dan resto Bangi Kopitiam di Kota Palu.

4. Untuk mengetahui dan menganalisis pengaruh atribut yang berhubungan dengan pembelian $\left(\mathrm{X}_{3}\right)$, berpengaruh terhadap perilaku pembelian ulang $(\mathrm{Y})$ konsumen di cafe dan resto Bangi Kopitiam di Kota palu.

\section{KAJIAN LITERATURE}

\section{Pengertian Pemasaran}

Kertajaya dalam Alma (2009:5) menyatakan bahwa pemasaran adalah sebuah disiplin bisnis strategis yang mengarahkan proses penciptaan, penawaran, dan perubahan nilai-nilai dari satu inisiator kepada stakeholder-nya. Menurut Kotler dan Keller (2009:13) pemasaran adalah proses sosial yang didalamnya terdapat individu dan kelompok mendapatkan apa yang mereka butuhkan dan inginkan, dengan menciptakan, menawarkan, dan secara bebas mempertukarkan produk yang bernilai dengan pihak lain. Subagyo (2010:4) menyatakan bahwa pemasaran adalah sebuah sistem bagian dari kegiatan bisnis yang dirancang untuk merencanakan, memberi harga, mempromosikan, dan mendistribusihkan, jasa serta barang-barang pemuas keinginan pasar. 
Berdasarkan pendapat para ahli di atas maka dapat disimpulkan bahwa pemasaran diarahkan untuk memenuhi dan memuaskan kebutuhan dan keinginan pembeli atau konsumen melalui proses pertukaran, serta pemasaran juga dikatakan adanya hubungan antara kelompok yang satu dengan yang lain dalam proses pertukaran yang terjadi, karena disebabkan adanya komunikasi, baik langsung maupun tidak langsung, sehingga menyebabkan terjadinya pertukaran tersebut.

\section{Pengertian Manajemen Pemasaran}

Menurut Sofjan Assauri (2013:12) Pengertian manajemen pemasaran adalah kegiatan menganalisis, merencanakan, melaksanakan dan mengendalikan program-program yang disusun dalam pembentukan, pembangunan, dan pemeliharaan keuntungan dari pertukaran/transaksi melalui sasaran pasar dengan harapan untuk mencapai tujuan organisasi (perusahaan) dalam jangka panjang.

Menurut Buchori dan Djaslim (2010:5) manajemen pemasaran adalah proses perencanaan dan pelaksanaan konsepsi, penetapan harga, promosi dan distribusi, gagasan, barang dan jasa. Untuk menghasilkan pertukaran yang memuaskan individu dan memenuhi tujuan organisasi, orientasi pemasaran dan berakhir pada tahap tanggung jawab sosial dan manusia.

\section{Kepuasan Konsumen}

Kepuasan konsumen dapat dirasakan setelah pelanggan membandingkan pengalaman mereka dalam melakukan pembelian barang/jasa dari penjual atau penyedia barang/jasa dengan harapan dari pembeli itu sendiri. Harapan tersebut terbentuk melalui pengalaman pertama mereka dalam membeli suatu barang/jasa, komentar teman dan kenalan, serta janji dan informasi pemasar dan persaingannya. Pemasar yang ingin unggul dalam persaingan tentu harus memperhatikan harapan konsumen serta kepuasan konsumennya. Menurut Kotler dan Keller (2009:206) kepuasan adalah perasaan senang atau kecewa yang muncul setelah membandingkan kinerja (hasil) suatu produk yang dipikirkan terhadap (kinerja atau hasil) yang diharapkan. Berdasarkan defenisi tersebut dapat dikatakan apabila kepuasan konsumen tidak sesuai dengan harapan konsumen dan bila harapan yang ditetapkan terlalu rendah, maka pengunjung tersebut akan merasa tidak puas dan berujung kecewa, jika kepuasan konsumen sesuai dengan harapan tamu cafe mereka akan merasa puas, namun apabila kepuasan konsumen melampaui harapan, maka tamu cafe akan merasa gembira dan sangat puas.

\section{Harapan Konsumen}

Olsen dan Dover dalam Tjiptono (2007:61) mengemukakan bahwa,"harapan konsumen merupakan keyakinan pelanggan sebelum mencoba atau membeli suatu produk,yang dijadikan standar atau acuan dalam menilai kinerja produk tersebut". Meskipun demikian dalam beberapa hal belum tercapai kesepakatan, misalnya mengenai sifat standar harapan yang spesifik jumlah standar yang digunakan, maupun sumber harapan. Harapan konsumen mempunyai peran yang besar dalam menentukan kualitas produk dan kepuasan konsumen. Harapan atas kinerja produk berlaku sebagai standar perbandingan terhadap kinerja aktual produk. Cara perusahaan mempromosikan produknya melalui komunikasi iklan atau wiraniaga juga dapat mempengaruhi harapan konsumen terhadap kinerja produk. Klaim produk yang tidak realistis bisa menimbulkan "over promise" yang akan menimbulkan ketidakpuasan pelanggan.

\section{Strategi Peningkatan Kepuasan}

Upaya mewujudkan kepuasan konsumen total bukanlah hal yang mudah menurut Tjiptono (2014:353) menyatakan bahwa secara sederhana kepuasan bisa diartikan sebagai upaya pemenuhan sesuatu atau membuat sesuatu memadai. Pada prinsipnya strategi kepuasan konsumen akan menyebabkan para pesaing harus bekerja keras dan memerlukan biaya tinggi dalam usahanya merebut pelanggan suatu perusahaan.

Fandy Tjiptono (2009:354-355) mengemukakan beberapa elemen program kepuasaan konsumen yang dapat dipadukan untuk meraih dan meningkatkan kepuasan konsumen. Strategi tersebut yaitu : 
1. Barang dan Jasa Berkualitas

2. Relationship marketing

3. Strategi superior customer service (fokus pada konsumen terbaik/best customers).

4. Strategi unconditional guarantess/extraordinary guarantees.

5. Program pay-for-performance

6. Program Promosi Loyalitas

7. Sistem Penanganan Keluhan Secara Efektif

\section{Metode Pengukuran Kepuasan Konsumen}

Menurut Kotler dan Keller (2009:115) beberapa metode yang dipergunakan dalam mengukur kepuasan konsumen. antara lain, yaitu sebagai berikut :

1. Sistem Keluhan dan Saran

Setiap organisasi jasa yang berorientasi pada pelanggan wajib untuk memberikan kesempatan bagi seluas-luasnya bagi para konumen untuk menyampaikan saran, kritik, pendapat dan keluhan mereka. Informasi yang didapatkan dari metode ini dapat menjadi masukan yang berharga bagi perusahaan sehingga memungkinkan untuk bereaksi dengan tanggap dan cepat dalam mengatasi masalah yang timbul. Akan tetapi metode ini pasif, sehingga sulit untuk mendapatkan gambaran secara lengkap mengenai kepuasan atau ketidakpuasan konsumen. Tidak semua konsumen yang tidak puas mau menyampaikan keluhannya. Sangat mungkin bagi mereka untuk langsung tidak mau membeli produk atau jasa dari perusahaan tersebut lagi.

2. Survei Kepuasan konsumen

Penelitian mengenai kepuasan umumnya banyak dilakukan dengan penelitian survei, baik survei melalui telepon, pos, angket, maupun wawancara secara pribadi.

3. Ghost shopping (pembelanja misterius)

Salah satu cara memperoleh gambaran kepuasan konsumen adalah dengan merekrut pekerja yang berperan sebagai konsumen kemudian melaporkan temuan-temuannya mengenai kekuatan dan kelemahan kualitas jasa perusahaan dan pesaing berdasarkan pengamatan mereka.

4. Lost customer analysis

Perusahaan seharusnya menghubungi konsumen yang sudah berpindah ke pesaing agar dapat memahami mengapa hal itu terjadi sebagai feedback dalam kebijakan perbaikan/penyepurnaan selanjutnya. Pemantauan ini sangat penting dimana peningkatan customer loss rate menunjukan kegagalan perusahaan dalam memuaskan konsumen.

\section{Atribut Kepuasan Konsumen}

Pernyataan Alan Dutka (2008:211) yaitu "Customer satisfaction is not just the name of department to customer satisfaction must be demonstrated throughout the company and integrated into all phases of the business". Penilaian kepuasan konsumen dapat diukur dengan menggunakan tiga atribut kepuasan konsumen. Menurut Dutka atribut tersebut adalah: atribut yang berhubungan dengan produk $\left(\mathrm{X}_{1}\right)$, atribut yang berhubungan dengan pelayanan $\left(\mathrm{X}_{2}\right)$, atribut yang berhubungan dengan pembelian $\left(\mathrm{X}_{3}\right)$.

\section{Pembelian Ulang}

Menurut teori Suryani dalam jurnal Rizal (2013:54) melakukan pembelian secara teratur atau berulang adalah pelanggan yang telah melakukan pembelian suatu produk sebanyak dua kali atau lebih. Sedangkan menurut teori Schiffman-Kanuk dalam jurnal Rizal (2013) ada dua tipe pembelian yaitu pembelian untuk percobaan dan pembelian ulang.

Pembelian percobaan merupakan tahap penyelidikan dari perilaku pembelian dimana konsumen berusaha mengevaluasi produk dengan mencoba. Jika suatu produk dibeli dengan percobaan ternyata memuaskan atau lebih memuaskan dari produk sejenis yang sebelumnya digunakan, maka konsumen 
berkeinginan untuk membeli ulang (Repurchase behavior). Menurut teori Yi dan Suna dalam Sahin A, Zehir C dan Kitapchi H (2012) Repurchase behavior dapat diukur melalui dua indikator yaitu :

1. Repeat Purchase Behavior: Repeat purchase behavior adalah pembelian yang dilakukan dalam intensitas yang berulang. Dalam penelitian ini Repeat purchase behavior adalah kondisi dimana konsumen memiliki tingkat intensitas akan kedatangan kembali di cafe dan resto Bangi Kopitiam di Kota Palu.

2. Repurchase Probability: Repurchase probability adalah suatu kemungkinan terjadinya pembelian kembali. Dalam penelitian ini maka Repurchase probability adalah kemungkinan yang dihadapi konsumen untuk datang kembali di cafe dan resto Bangi Kopitiam di Kota Palu.

\section{Siklus Pembelian Ulang}

Menurut Griffin (2013:35) menerangkan bahwa Pembelian ulang adalah orang-orang/konsumen yang telah membeli dari satu kali atau lebih. Mereka mungkin telah membeli produk yang sama dua kali atau membeli salah satu produk atau jasa pada satu perusahaan saja pada dua kesempatan atau lebih.
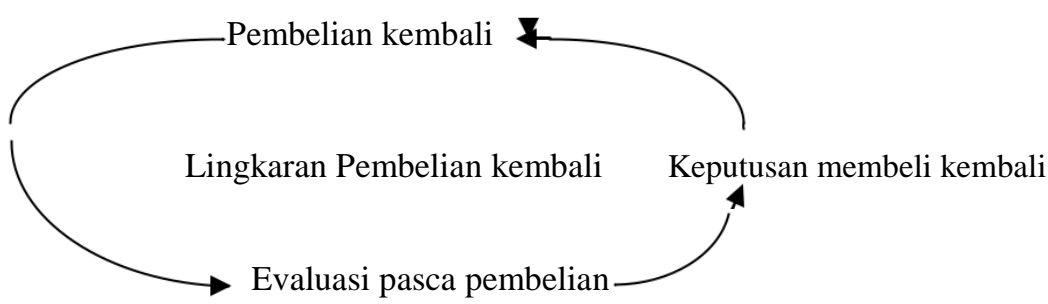

Kesadaran $\longrightarrow$ Pembelian awal

\section{Gambar 1 Siklus pembelian}

\section{Faktor-Faktor Yang Mempengaruhi Perilaku Pembelian Ulang}

Terjadinya suatu keputusan dari pembeli sangat dipengaruhi oleh faktor kebudayaan, sosial, pribadi, dan psikologi dari pembeli. Sebagian besar pembeli adalah faktor yang tidak dapat dikendalikan oleh pemasar, tetapi harus benar-benar diperhitungkan. Kotler dan Keller (2009:223) menjelaskan bahwa terdapat faktor-faktor yang dapat mempengaruhi perilaku konsumen yaitu:

1. Faktor Kebudayaan

Yang terdiri dari kultur, sub-kultur dan kelas sosial pembeli.

2. Faktor Sosial

Di mana perilaku konsumen dipengaruhi faktor-faktor seperti kelompok acuan (kelompok referensi) keluarga.

3. Faktor Pribadi

Kepuasan seseorang pembeli dipengaruhi karakteristik pribadi yaitu tahap siklus hidup, kondisi ekonomi, gaya hidup, serta kepribadian dan konsep diri.

4. Faktor Psikologis

Pilihan pembelian seseorang dipengaruhi oleh faktor motivasi, persepsi pengetahuan (Learning) serta keyakinan dan sikap. 


\section{Kerangka Pemikiran}

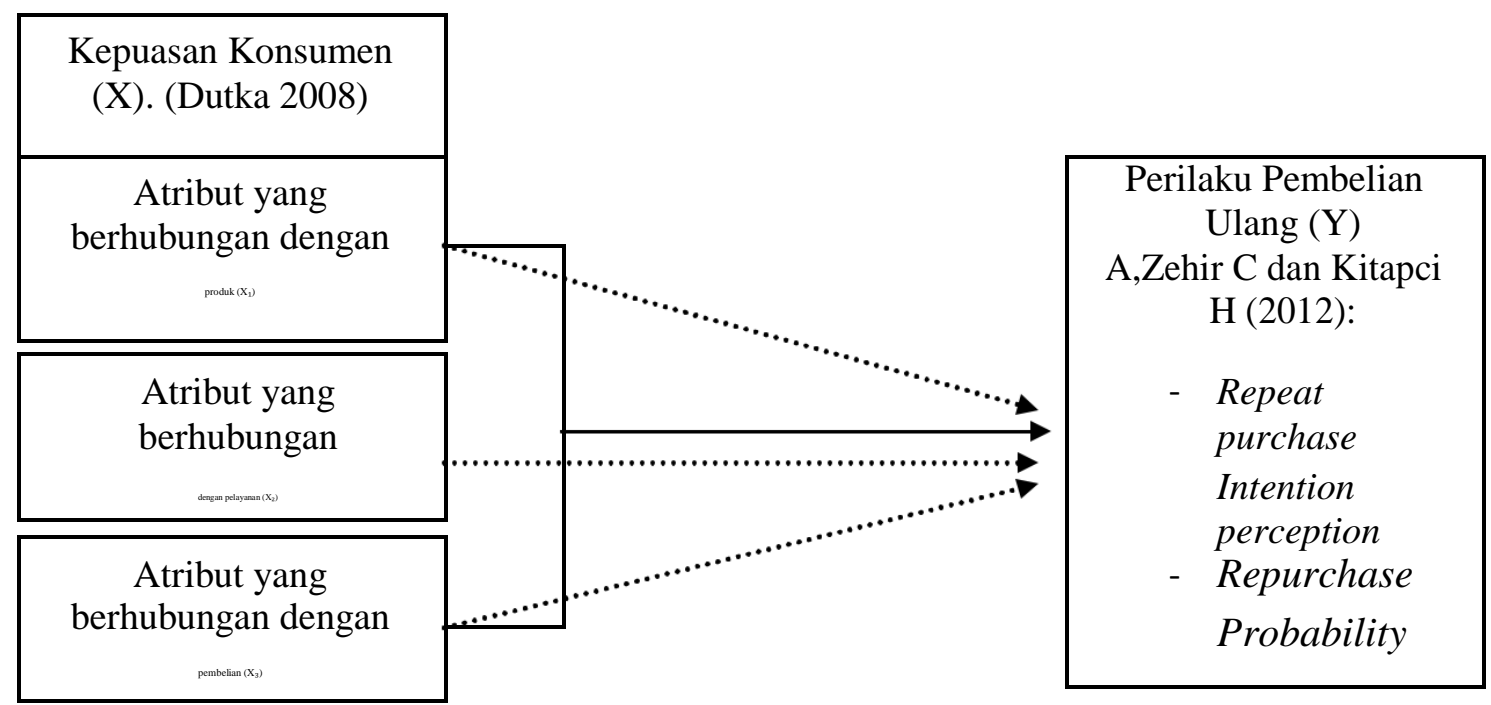

\section{Gambar 2 Kerangka Pemikiran}

\section{Keterangan}

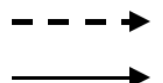
Berpengaruh secara parsial
Berpengaruh secara simultan

\section{Hipotesis}

Berdasarkan teori dan kerangka berpikir diatas dapat disusun beberapa hipotesis sebagai berikut:

1. Dimensi kepuasan konsumen yang terdiri dari atribut yang berhubungan dengan produk $\left(\mathrm{X}_{1}\right)$, atribut yang berhubungan dengan pelayanan $\left(\mathrm{X}_{2}\right)$, dan atribut yang berhubungan dengan pembelian $\left(\mathrm{X}_{3}\right)$. Secara simultan mempunyai pengaruh positif dan signifikan terhadap perilaku pembelian ulang konsumen di cafe dan resto Bangi Kopitiam di Kota Palu.

2. Atribut yang berhubungan dengan produk $\left(X_{1}\right)$, mempunyai pengaruh positif dan signifikan terhadap perilaku pembelian ulang konsumen di cafe dan resto Bangi Kopitiam di Kota Palu.

3. Atribut yang berhubungan dengan pelayanan $\left(X_{2}\right)$, mempunyai pengaruh positif dan signifikan terhadap perilaku pembelian ulang di cafe dan resto Bangi Kopitiam di Kota Palu.

4. Atribut yang berhubungan dengan pembelian $\left(\mathrm{X}_{3}\right)$, mempunyai pengaruh positif dan signifikan terhadap perilaku pembelian ulang di cafe dan resto Bangi Kopitiam di Kota Palu.

\section{METODE PENELITIAN}

Tipe penelitian yang dikakukan adalah deskriptif-kausal dalam menjelaskan pengaruh antar variabel kepuasan konsumen (X) dan perilaku pembelian ulang (Y). Penelitian kausal merupakan penelitian yang bertujuan untuk membuktikan hubungan sebab akibat atau hubungan mempengaruhi dan dipengaruhi dari variabel-variabel yang diteliti yaitu independen dan dependen (Istijanto, 2006).

Teknik pengambilan dan pengumpulan data yang dilakukan dengan cara:

1. Observasi, yaitu berupa penelitian lapangan terhadap karakteristik responden antara lain kepuasan konsumen $(\mathrm{X})$ dan perilaku pembelian ulang $(\mathrm{Y})$.

2. Kuesioner, yaitu mengajukan pertayaan yang harus dijawab oleh responden antara lain data varibel kepuasan konsumen dan perilaku pembelian ulang.

3. Wawancara, yaitu teknik pengumpulan data dengan melakukan wawancara langsung kepada konsumen dan karyawan cafe dan resto Bangi Kopitiam,data informasi tersebut adalah untuk melengkapi sekaligus Cross check data yang dikumpulkan melalui kuesioner. 
4. Dokumentasi, yang berkaitan dengan buku, laporan publikasi, dan bukti lainnya yang berkaitan dengan penelitian.

\section{Variabel bebas (Independent Variable)}

Variabel bebas $(\mathrm{X})$ pada penelitian ini adalah kepuasan konsumen merupakan sikap, penilaian, dan respon emosional yang ditujukan oleh konsumen setelah proses pembelian/konsumsi yang berasal dari perbandingan kesannya terhadap suatu produk dan harapannya, serta evaluasi terhadap pengalaman mengkonsumsi suatu produk atau jasa. Menurut Alan Dutka (2008:211) atribut tersebut adalah: atribut yang berhubungan dengan produk $\left(\mathrm{X}_{1}\right)$, atribut yang berhubungan dengan pelayanan $\left(X_{2}\right)$, dan atribut yang berhubungan dengan pembelian $\left(X_{3}\right)$.

\section{Variabel Terikat (Dependent Variable)}

Variabel terikat (Y) pada penelitian ini adalah perilaku pembelian ulang dapat diukur melalui dua indikator yaitu:

a. Repeat purchase intention: Repeat purchase intention adalah pembelian yang dilakukan dalam intensitas yang berulang. Dalam penelitian ini Repeat purchase intention adalah kondisi dimana konsumen memiliki tingkat intensitas akan kedatangan kembali di cafe dan resto Bangi Kopitiam di Kota Palu.

b. Repurchase probability:Repurchase probability adalah suatu kemungkinan terjadinya pembelian kembali. Dalam penelitian ini maka Repurchase probability adalah kemungkinan yang dihadapi konsumen untuk datang kembali di cafe dan resto Bangi Kopitiam di Kota Palu.

Populasi dalam penelitian ini adalah masyarakat di Kota Palu yang pernah melakukan pembelian ulang di cafe dan resto Bangi Kopitiam. Jumlah populasi dalam penelitian ini tidak dapat diketahui dengan pasti, maka perlu digunakan sebuah metode khusus untuk mempermudah penentuan jumlah sampel yang akan digunakan.

Metode penarikan sampel yang digunakan dalam penelitian ini adalah dengan cara accidental sampling, Menurut Sugiono (2013:122) accidental sampling adalah teknik penarikan sampel berdasarkan kebutulan. Dikarenakan dalam teknik sampel ini, yang dianggap sebagai anggota sampel adalah orang-orang yang mudah ditemui atau yang berada pada waktu yang tepat, mudah dijangkau dan ditemui, yang berada di tempat cafe dan resto Bangi Kopitiam lebih dari satu kali membeli ulang di cafe dan resto Bangi kopitiamdi Kota Palu.

Mengingat jumlah populasi yang tidak diketahui dengan pasti, maka sampel dihitung berdasarkan indikator yang digunakan, Augusty Ferdinand (2009:48) yang berpendapat bahwa: besarnya sampel tergantung pada jumlah indikator yang digunakan dalam sebuah variabel. Jumlah sampel adalah jumlah indikator dikali minimal 5 sampai 10. Penelitian ini memiliki 18 indikator atau estimated parameter. Dengan mempertimbangkan efesiensi dan efektifitas penelitian maka penulis menggunakan nilai terendah dari jumlah indikator digunakan sebagai faktor penggali untuk menentukan jumlah sampel yang digunakan dalam penelitian ini. Demikian, jumlah sampel yang digunakan dalam penelitian ini adalah $18 x 5$ yaitu sebanyak 90 sampel.

Penelitian ini menggunakan aplikasi software SPSS (Statistical Program for Social Scane) versi 18.0 yang dipakai untuk menganalisis pengaruh secara simultan dan pengaruh secara parsial variabel Independen terhadap dependen. Adapun teknik analisis data yang dipergunakan dalam penelitian ini yang terdiri dari analisis regresi linier berganda. Analisis. Metode penelitian menurut Sugiyono (2014:277) adalah suatu teknik atau cara mencari, memperoleh, mengumpulkan, mencatat data, baik primer maupun sejunder, model umum bentuk persamaan alat analisis statistic parametric regresi linear berganda dapat digambarkan sebagai berikut persamaan struktural dalam model sebagai berikut:

$\mathbf{Y}=\mathbf{a}+\mathbf{b}_{1} \mathbf{X}_{1}+\mathbf{b}_{2} \mathbf{X}_{2}+\mathbf{e}$ 
Di mana:

$\mathrm{Y}=$ Keputusan Konsumen

$\mathrm{X}_{1}=$ Atribut yang berhubungan dengan produk

$\mathrm{X}_{2}$ = Atribut yang berhubungan dengan pelayanan

$\mathrm{X}_{3}=$ Atribut yang berhubungan dengan pembelian

A $=$ Konstanta

$\mathrm{b}_{1-} \mathrm{b}_{2}=$ Koefisien Regresi

4. HASIL DAN PEMBAHASAN

Analisis Regresi Berganda

Tabel 1 Hasil Analisis Regresi Linear Berganda

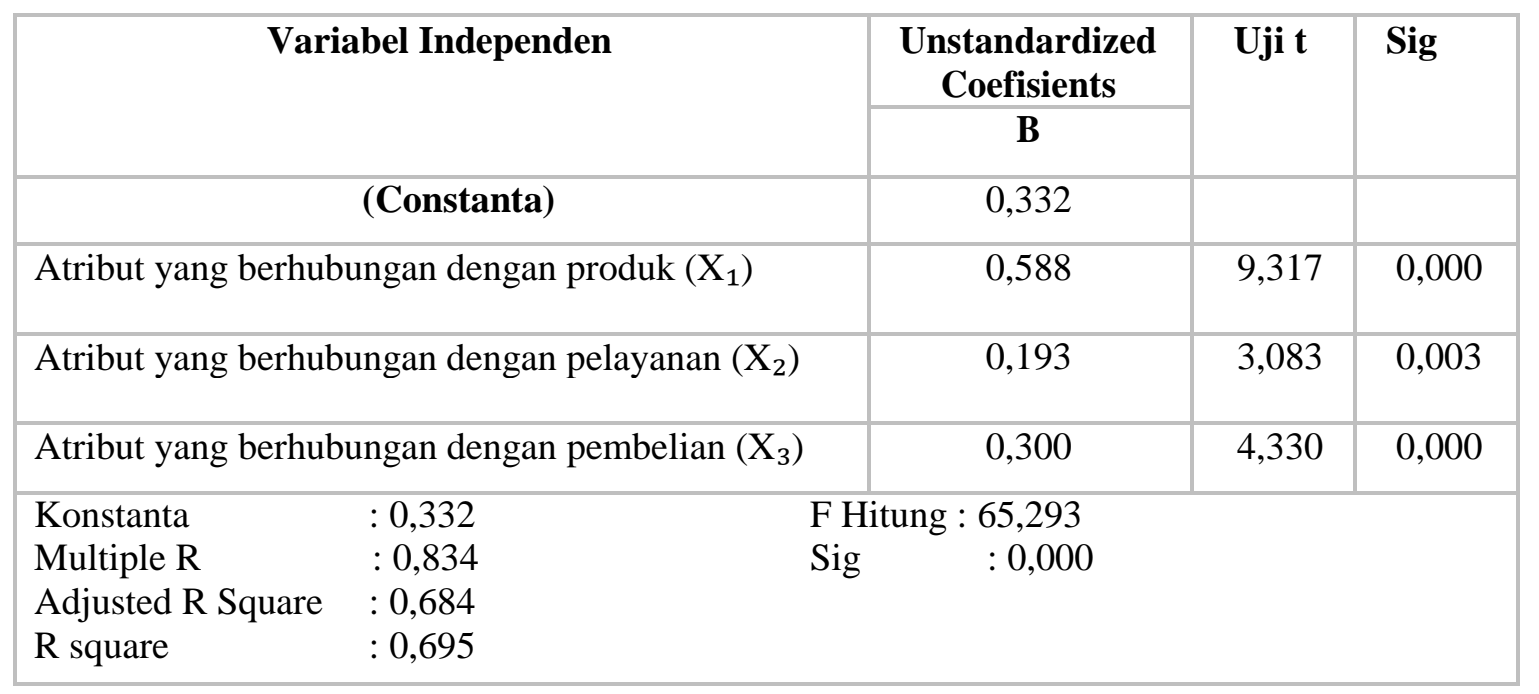

Berdasarkan hasil tersebut apabila ditulis dalam bentuk persamaan regresinya adalah sebagai berikut:

$$
\mathrm{Y}=\mathbf{0 , 3 3 2}+\mathbf{0 , 5 8 8 X 1}+\mathbf{0 , 1 9 3 X 2}+\mathbf{0 , 3 0 0 X 3}
$$

\section{Pembahasan}

\section{Pengujian Hipotesis Pertama (Uji F)}

Berdasarkan hasil uji ANOVA (Analysis of Varians) atau F test diperoleh nilai $\mathrm{F}$. sebesar 65,293 dengan signifikansi 0,000 dengan nilai $\alpha$ (batas signifikan) adalah 0,05 . Sehingga dapat diketahui bahwa $0,000<0,05$ maka model analisis regresi ini dinyatakan signifikan,dengan demikian (Ho) ditolak dan ( $\mathrm{Ha}$ ) diterima, karena terdapat pengaruh antara variabel independen atribut yang berhubungan dengan produk $\left(\mathrm{X}_{1}\right)$, atribut yang berhubungan dengan pelayanan $\left(\mathrm{X}_{2}\right)$, dan atribut yang berhubungan dengan pembelian $\left(\mathrm{X}_{3}\right)$ secara simultan terhadap variabel dependen perilaku pembelian ulang (Y) konsumen di cafe dan resto Bangi Kopitiam di Kota Palu.

\section{Pengujian Hipotesis (Uji t)}

1. Atribut yang berhubungan dengan produk $\left(\mathrm{X}_{1}\right)$, nilai signifikansinya sebesar 0,000 . Karena angka probabilitas signifikansi $<0,05$ diterima, dengan demikian atribut yang berhubungan dengan produk $\left(\mathrm{X}_{1}\right)$ signifikan terhadap perilaku pembelian ulang $(\mathrm{Y})$.

2. Atribut yang berhubungan dengan pelayanan $\left(X_{2}\right)$, nilai signifikansinya sebesar 0,003 . Karena angka probabilitas signifikansi $<0,05$ diterima, dengan demikian atribut yang berhubungan dengan pelayanan $\left(\mathrm{X}_{2}\right)$ signifikan terhadap perilaku pembelian ulang $(\mathrm{Y})$. 
3. Atribut yangberhubungan dengan pembelian $\left(X_{3}\right)$, nilai signifikansinya sebesar 0,000 . Karena angka probabilitas signifikansi $<0,05$ diterima, dengan demikian atribut yang berhubungan dengan pembelian $\left(\mathrm{X}_{3}\right)$ signifikan terhadap perilaku pembelian ulang $(\mathrm{Y})$.

\section{Koefisien Determinasi $\left(\mathbf{R}^{2}\right)$}

Tabel 2 Koefisien Determinasi

\begin{tabular}{|l|c|r|r|r|}
\hline \multicolumn{6}{|c|}{ Model Summary $^{\mathbf{b}}$} \\
\hline Model & $\mathrm{R}$ & $\begin{array}{c}\mathrm{R} \\
\text { Square }\end{array}$ & $\begin{array}{c}\text { Adjusted R } \\
\text { Square }\end{array}$ & $\begin{array}{c}\text { Std. Error of the } \\
\text { Estimate }\end{array}$ \\
\hline 1 &, $834^{\mathrm{a}}$ &, 695 &, 684 &, 23985 \\
\hline
\end{tabular}

Koefisien korelasi (R) memiliki nilai sebesar 0,834 yang artinya bahwa variabel yang diteliti yaitu atribut yang berhubungan dengan produk $\left(\mathrm{X}_{1}\right)$, atribut yang berhubungan dengan pelayanan $\left(\mathrm{X}_{2}\right)$, dan atribut yang berhubungan dengan pembelian $\left(\mathrm{X}_{3}\right)$ sangat berpengaruh dengan variabel terkaitnya sebesar 0,834 atau sebesar $83,4 \%$.

\section{KESIMPULAN DAN SARAN}

\section{Kesimpulan}

1. Dimensi kepuasan konsumen yang terdiri dari atribut yang berhubungan dengan produk $\left(\mathrm{X}_{1}\right)$, atribut yang berhubungan dengan pelayanan $\left(X_{2}\right)$, dan atribut yang berhubungan dengan pembelian $\left(\mathrm{X}_{3}\right)$, Secara serempak mempunyai pengaruh positif dan signifikan terhadap perilaku pembelian ulang (Y), konsumen di cafe dan resto Bangi Kopitiam di Kota Palu.

2. Atribut yang berhubungan dengan produk $\left(X_{1}\right)$, mempunyai pengaruh positif dan signifikan terhadap perilaku pembelian ulang (Y), konsumen di cafe dan resto Bangi Kopitiam di Kota Palu.

3. Atribut yang berhubungan dengan pelayanan $\left(\mathrm{X}_{2}\right)$, mempunyai pengaruh positif dan signifikan terhadap perilaku pembelian ulang (Y), konsumen di cafe dan resto Bangi Kopitiam di Kota Palu.

4. Atribut yang berhubungan dengan pembelian $\left(X_{3}\right)$, mempunyai pengaruh positif dan signifikan terhadap perilaku pembelian ulang (Y), konsumen di cafe dan resto Bangi Kopitiam di Kota Palu.

\section{Saran}

1. Sebaiknya cafe dan resto Bangi Kopitiam harus lebih memaksimalkan lagi pelayanan yang berorientasi kepuasan konsumen yang meliputi: atribut yang berhubungan dengan produk (X1), yaitu dengan melalui harga yang ditetapkan pada setiap produk yang ditawarkan sudah sesuai, makanan yang dijual memiliki cita rasa yang baik, produk dan fasilitas pelayanan yang diberikan oleh cafe dan resto Bangi Kopitiam sudah cukup baik, makanan yang di jual memiliki desain yang menggoda selera, makanan yang di jual tidak kalah dengan para pesaingnya, setiap fasilitas produk yang ditawarkan beranekaragam.

Atribut yang berhubungan dengan pelayanan (X2), yaitu dengan melalui cafe dan resto Bangi Kopitiam memberi jaminan atas produk yang mereka tawarkan apabila layak konsumsi dan halal, produk makanan yang ditawarkan merupakan produk unggulan, pelayanan yang diberikan cepat, jika terdapat complain dari konsumen pihak cafe dan resto Bangi Kopitiam selalu memberikan solusi atas masalah yang dihadapi oleh konsumen, cafe 
dan resto Bangi Kopitiam cukup tanggap dalam menyelesaikan masalah dengan konsumennya.

Atribut yang berhubungan dengan pembelian (X3), yaitu dengan melakukan komunikasi karyawan dengan konsumen cukup baik, penampilan karyawan cukup rapi, Reputasi cafe dan resto Bangi Kopitiam cukup baik di mata masyarakat, pelayanan selalu cepat dan tepat, tidak ada kesulitan dalam melakukan pembelian produk makanan. Ketiga dimensi ini mempunyai pengaruh yang signifikan terhadap perilaku pembelian ulang (Y). Cafe dan resto Bangi Kopitiam sebaiknya harus lebih baik lagi dalam melakukan pelayananpelayanan serta lebih memperbanyak lagi memberikan varian rasa dalam produk makanan yang di jual.

2. Sebaiknya untuk penelitian selanjutnya dapat mencari teori yang lebih banyak lagi dan menambah variabel lain dalam penelitian agar dapat menambah pengetahuan si pembaca.

3. Sebaiknya pimpinan/manager cafe dan resto Bangi kopitiam sebaiknya memberikan kemudahan serta perizinan bagi setiap mahasiswa yang ada khusunya di Kota Palu yang ingin melakukan penelitian pada perusahaan tersebut.

\section{REFERENSI}

Ahmad, Rizal. (2013). Pengaruh Kualitas Pelayanan, Kualitas Produk, dan Harga Terhadap Kepuasan Konsumen Untuk Mendorong Pembelian Ulang (Studi Kasus pada PT.Restomart Cipta Usaha Cabang Semarang). Jurnal Dinamika Manajemen, Vol 2, No 2, Hal.65-80.

Ahmad, Subagio. (2010). Marketing In Business. Jakarta: Mitra Wacana Media.

Buchari, Alma. (2009). Manajemen Pemasaran dan Pemasaran Jasa. Cetakan ke delapan. Bandung: Alfabeta.

A, Zehir, C, Kitapchi H. (2012). "The effect of Brand Experience and Service Quality on Repurchase Intention: the Role of Brand Relationship Quality.

Assuari, Sofjan. (2013). Manajemen pemasaran. Jakarta: Rajagrafindo Persada.

Dutka, Alan. (2008). AMA Hand book of Customer Satisfaction:A Complete Guide to Research Planning and Implementation, NTC Busing Book, Illinois.

Djaslim, dan Buchori. (2010). Manajemen pemasaran. Bandung: Linda Karya.

Ferdinand, Augusty. (2009). Metode penelitian manajemen. Edisi ketiga. Universitas Diponegoro:

Semarang.

Griffin. (2013). Customer loyalty. Edisi Revisi dan Terbaru. Jakarta: PT. Erlangga.

Istijanto. (2006). Riset Sumber Daya Manusia. Edisi kedua. Jakarta: PT.Gramedia Pustaka.

Kotler, Philip and Keller, Kevin Lane. (2009). Manajemen Pemasaran. Edisi Bahasa Indonesia

Cetakan Kedua, Edisi 13, Jilid 2. Alih Bahasa: Bob Sabran. Jakarta: PT. Erlangga.

Sugiono. (2013). Metode penelitian bisnis (pendekatan kuantitatif, kualitatif, dan R\&D) .Bandung:

Alfabeta.

Sugiyono. (2014). Metodologi Penelitian Manajemen. Cetakan Ke-3, Bandung: Alfabeta.

Tjiptono, Fandy. (2007). Service Management: Mewujudkan Layanan Prima. Edisi Pertama, Yogjakarta: Andi.

Tjiptono, Fandy. (2014). Pemasaran jasa. Malang: Bayumedia.

Tjiptono, Fandy. (2009). Strategi pemasaran. Edisi ketiga. Yogyakarta: Andi. 